\title{
Fastfood eller finlitteratur?
}

\section{Tendenser i moderne amerikansk fiktion}

Hvis man vil beskrive både ensartetheden og spændvidden og modsætningerne i Amerikansk kultur og litteratur, kan man starte med to udsagn, som indbyrdes modsiger hinanden.

Udsagn 1 : USA er et land med ca. 240 mill. mennesker. På grund af dets historie med de mange indvandringsbølger, består det af mange forskellige nationale og etniske grupper med hver deres specifikkc kultur. Hver del af USA, ja hver af de 50 stater har sit særprag. Det er umuligt at sige noget éntydigt om amerikansk kultur.

Udsagn 2: Den amerikanske kultur er en enhedskultur, skabt af en dynamisk kapitalistisk økonomi og en optimistisk liberalistisk ideologi. Den styres af højteknologien og massemedierne, og dens produkter er industrielt designede og fastfood. Hvad der skulle vare af subkulturer opsuges og ensrettes af den herskende industrikultur.

Dette sidste syn på USA er eneherskende $\mathrm{i}$ den franske postmodernistiske filosof Jean Baudrillards bog om Amerika (1986, da. 1987). For ham er USA det postmoderne paradis, hvor simulacrerne, billederne uden indhold, fra drømmcfabrikken Hollywood og fra TV-skærmene fortryller alle. Han ser kun ensartetheden: materialismen, kvantitetsdyrkelsen, promiskuiteten og narcissismen. Både ironisk og varmt accepterende ser han USA som den virkeliggjorte utopi, fordi der her ikke længere som i den vesteuropaiske tradition eksisterer en forskel i bevidstheden mellem drom og virkelighed. Sclv samfundskritikken er kun et tegn på systemets sundhed.

Overfladisk set virker det, som Baudrillard har ret. Den litteræere kulturindustri dominerer bestseller-listerne, og de genrer, der speciclt dyrkes af læserne, er de samme, som konsumeres af seerne: spændingsromaner, krimien, gyseren og romancer, enten i historiske gevanter eller blandt den nutidige ovcrklasse i Californien, Texas eller Now York. Bestsellerne købes af Hollywood, og helt ned i skrivemåden kan man se,hvordan forfatterne altid tænker på mulighederne for filmatisering. 
Og alligevel: Stephen Kings gysere ville vare utænkelige uden forfatterens rødder i den kolde, landlige nordøst-stat Mainc, Tony Hillerman har fået stor succes med detektiver fra Navajo-stammen i New Mexico. Når vi bevæger os til litteraturen med et mere seriøst sigte, bliver forskellen i gcografisk, historisk og etnisk baggrund endnu tydligere. Baudrillards USA er et billede, der kun ser de centrifugale kræfter i amerikansk kultur, eller som Arno Victor Nielsen skrev i Politiken: et USA set gennem bilruden. Min gennemgang af tendenser i nycre amcrikanske littcratur vil tage sit udgangspunkt i forskellene. Da artiklen bygger på et fordrag for folkebibliotekarer, focuserer jeg overvejende, men ikke udelukkende, på fiktion, der er oversat til dansk.

\section{Jфderne}

Hvis man ser på hvilke forfattere, der har præget amerikansk efterkrigslitteratur, og hvilke, vi kender herhjemme gennem oversættelser, så er det forbløffende, hvor mange af dem, der har en jødisk baggrund: Saul Bellow, E.L. Doctorow, Allen Ginsberg, Joseph Heller, Erica Jung, Normann Mailer, Bernard Malamud, Arthur Miller, Tillic Olsen, Cynthia Ozick, Grace Paley, Marge Piercy (halv-jøde), Philip Roth, J. D. Salinger (halv-jøde). Et særligt tilfælde er Isaac B. Singer, der har boet i New York siden 1935, men som skriver på jiddisch og primæert på erindringer og temaer fra den gamle polsk-jødiske kultur. Inden for kulturindustrien er der jødiske bestseller-forfattere som Irvin Shaw, Leon Uris og Herman Wouk. Ret imponerende i betragtning af at jøderne kun udgør $21 / 2 \%$ af den amerikanske befolkning, dvs. ca. 6 millioner.

De jødiske forfattere brød for alvor igennem i USA i den umiddelbare efterkrigstid, og man har kaldt 1950'erne for det jødiske årti i amerikansk litteratur. Forfatterne var ofte børn af emigrantforældre, og de profiterede både af de forbedrede uddannelsesmuligheder i USA og af den jødiske tradition for intellektuelt arbejde. Den jødiske amerikanske efterkrigslitteratur var præget af marxismens og dermed socialrealismens sammenbrud i slutningen af 30 'rne, af Holocaust-erfaringen og af en litterær orientering i retning af europxisk modernisme og tildels eksistentialisme. Den jødiske litteratur i USA blev en storbylitteratur, hvor man focuserede på psykologiske og moralske problemtillinger, og hvor man så de sociale landskaber, storbyerne som metaforer for psykologiske og eksistentielle dilemmaer. ${ }^{2}$ Den jødiske litteratur fik et strikt intellektuclt præg, samtidig med at den ofte var farvet af en speciel jødisk selvironisk sort humor. 
Den jødiske dominans i amerikansk efterkrigslitteratur fik sit officielle verdenslitterære stempel med tildelingen af nobelprisen i 1976 til Saul Bellow og i 1978 til Isaac B. Singer. Af de tidligere næunte forfattere er det kun Malamud, der er død (1986), og selv om de andre er aldre eller midaldrende, er de stadig yderst produktive og udgør en form for litterært establishment i USA.

Saul Bcllows sidste roman, Der er flere der dør af hjertesong (1987, da. 1988) gennemspiller to af Bellows traditionelle ynglingstemaer: behovet for en holdbar filosofisk fortolkning af den moderne »posthistoriske « amcrikanske virkelighed og en kortlægning af sexualitetens dæmoniske indflydelse. Titlen er også typisk Bellowsk og refererer til hovedpersonen, botanik-professorens Ben Craders reaktion på en journalists spørgsmål om strålefaren fra Tremileøen og Tjernobyl. Selvfølgelig er den et problem, svarer han, men hjertesorgen er et større. Bellow er i højere og højere grad blevet de moralske og erotiske krisers forfatter, mens hans politiske og ideologiske synspunkter, hvis de overhovedet fremsættes, er blevet mere udpraget konservative. (Det er derfor helt logisk, at Bellow har skrevet et anbefalende forord til universitetskollegaen fra Chicago Allan Blooms bestseller The Closing of the American Mind (1987) med dens begrædelse af det amerikanske dannelsestab.)

I Der er flere der dør af hjertesorg gennemdiskuterer Ben Crader og hans nevø Kenneth, bogens fortæller, kærlighedens problemer. Ben er blevet lokket ind i et nyt ægteskab, som hurtigt viser sig at være grundet på meget materielle interesser fra brudens side. Også Kenneth har synlige ar fra køns-kampens slagmark. Det er ikke nemt for de bløde jødiske intellektuelle mænd at klare sig blandt de barske ikke-jødiske kvinder i et materialistisk USA. Kenneth har af sin lærer i Paris, en russisk mystiker, lært - og det er givetvis bogens »budskab« - at det moderne menneske ikke har kunnet integrere sexualiteten i sjælen. Sexualiteten er blevet dæmoniseret, således at man i modsætning til Østeuropa, hvor man lider under »afsavnenes byrde« - i Vesten lider under »begarets byrde«. Sexualiteten er blevet den dæmoniske og dermed forgæves måde at genvinde paradiset på. Efter atombomben har man fåct orgasmebomben! I det posthistoriske USA har den økonomiske dynamiks bagside iflg. Bellow været den psykiske rastløshed, en manglende focusering $i$ bevidsheden og magtens og voldens indtog i erotikken.

Som altid hos Bellow kører der en kværnende filosofisk monolog, hvor bevidstheden fors $\emptyset$ ger at gribe materialiteten, men altid kommer til kort. Med det ene ben står Bellow i den typisk modernistiske situation, hvor matcrialismen og fremmedgørclsen i det amerikanske storbyliv søges 
forklaret i én stor syntetiserende fortolkning, med det andet midt i den postmoderne, hvor synteser ikke lindes.

I sin nyeste bog, novellaen $A$ Theft $(1989$, da. 1989) fors $ø$ ger Bellow for første gang at se den midaldrendes erotiske situation fra en kvindes synsvinkel, men det kommer der ikke noget nyt ud af, og novellen mangler Bellows humor, hans skarpe blik for smågangsterne og de skæve eksistenser i den amerikanske metropolis.

Med sin debut, novellesamlingen Farvel Columbus (1959), fremstod Philip Roth som jødernes enfant terrible, satirikeren, selvhaderen og $\mathrm{i}$ visse kredsc, som forræderen mod »den jødiske sag«. Disse reaktioner var kun en ouverture til dem, der fulgte på skandalesuccessen Portnoys genvordigheder (1969, da. 1969), der tegnede et billede af en sexuel desperado og forræder mod det helligste af alt: den jødiske familic. Roths bøger er blevet læst som udsagn vendt mod det jødiske samfund i USA, en hån mod Holocaust-ofrene og som illoyale sclvbiografier. Læserreaktionerne har sporet den tydeligt hudløse forfatter i retning af metaliktionen, hvor problemet kunst/liv kunnc diskuteres. Den jødisk-amerikanske forfatterperson Nathan Zuckerman har bredt sig fra vark til værk som Roths delvise talerør.

Zuckerman-figuren lancerede Roth allerede i Mit liv som mand (1970, da. 1972). Her er han en romanperson, som forfatteren Peter Tarnopol bruger i to kapitler, »Useful fiction «, til at belyse forskellige sider af en erotisk konflikt. I bogens sidste og største del »My True Story« skriver Tarnopol sin egen dybt traumatiske kærlighedshistoric. Tarnopol bruger altså Zuckerman, ligesom Roth bruger Tarnopol til at objcktivere og fiktionalisere en historic, læseren fornemmer er uhyre subjektiv, dvs. selvbiografisk, hvilket Roths selvbiografi The Facts (1988) til fulde bekæfter.

I den egentlige Zuckerman-serie ${ }^{3}$ er Tarnopol-figuren forsvundet. Zuckerman får »eget liv« og rykker tættere på forfatteren. Zuckermans forfatterskab og reaktionerne på det minder slående om Roths forfatterimage. Alligevel tordner Zuckerman, specielt i Den befriede Zuckerman, mod lasernes sammenblanding af facts og fiktion.

Da Roth i 1986 udsendte Zuckerman-bøgerne i ét bind, Zuckerman Bound, åndede kritikerne op. Dette må være gravstenen på Zuckermans liv, og Roth burde nu vare fri til at fornye sig. Og hvad hændte? Sencre samme år udgav han en ny Zuckerman-bog, The Counterlife (da. 1989), som på én gang repeterede alle de forrige bøgers temacr og samtidig intensiverede behandlingen af $\mathrm{dem}$ ved at indskrive dem i Roths hidtil mest avancerede brug af metafiktionen.

Det saregne ved The Counterlife cr, at hvert kapitcl kan lases 
realistisk, men at det næste kapitel placerer personerne i nye situationer, som ophæver realismen i det foregående. I romanens fjerde del afsløres det, at de foregående kapitler og det kommende alle er fragmenter af en roman, som Zuckerman har skrevet på, og hvori han afprøver forskellige beskrivelser af det at være jøde. Zuckermans bror finder efter hans død manuskriptet, bliver rasende over at være misbrugt i fiktionen og destruerer papirerne. Sporet ind på de andre kapitlers ikke-realisme og fiktionalitet tvinges læseren til også at opfatte Zuckermans død som fiktion og i sidste instans at opfatte alle virkelighedsbeskrivelser som fiktion. »We are all each other's authors«, som det hedder s. 145.

Med The Counterlife placerer Roth sin fiktion centralt $\mathrm{i}$ den postmoderne, metafiktive eller dekonstruktionistiske tradition, som i amerikansk litteratur repræsenteres af forfattere som William Burroughs, John Barth, Thomas Pynchon, William Gass o.m.a., men han får samtidig belyst den store fortælling om at være amerikansk jøde fra flere sider end nogensinde $f ø r$.

Og for at det ikke skal være løgn udsendte Roth i 1988 en selvbiografi The Facts. A Novelist's Autobiography, hvor - som man kan se - undertitlen dementerer genrens tilsyneladende enkelthed. Indledningsvis sender Roth sit manuskript til Zuckerman (hvem ellers?) og spørger ham, om han skal udgive det. Epilogen udgøres af Zuckermans litteraturkritiske nedsabling af selvbiografien. Den fiktive person afslører alle autobiografens fejl: idylliseringerne, fikseringerne, forskønnelserne og dæmoniseringerne. Zuckermans råd er: lad være at udgive den, din fiktion er meget mere agte og vedkommende. En konklusion, der rummer den fare for Zuckerman, at han vil blive vakt »til live « igen i en ny roman, hvad han jo faktisk allerede er her, hvor selvbiografiens ramme afslører, at dødsfaldet i The Counterlife også var fiktion.

Med romanerne Daniels bog (1971, da. 1977), Ragtime (1975, da. 1976) og Lomsøen (1980, da. 1981) specialiserede E.L. Doctorow sig i den historiske roman, en række mytiske billeder af USA i historiske konfliktsituationer i dette århundrede, hvor tendenser til oprør knuses af systemets egen dynamik og overlevelsesevne. I sin interesse for hele landets historie viser han sig mere som amerikansk end som etnisk forfatter, mindre fikseret på det at være jøde. Og dog er Daniels bog et næten rent jødisk drama, som bygger på Rosenberg-sagen, hvor et jødisk kommunistisk ægtepar i McCarthy-æraen i begyndelsen af 1950'erne dømmes og henrettes som russiske spioner. Ved at lade deres børn være hovedpersoner i bogen peger Doctorow på det stærke jødiske engagement i både 30'r-kommmunismen og i 1960'ernes ungdomsoprør. 
I 80'crne vendte Doctorow sig fra den store til den lille historie, først med novcllesamlingen Digternes liv (1984, da. 1986) og sencre med erindringsromanen Verdensudstilling (1985, da. 1987), hvor han valgte frøperspektivet, idet han skildrer en lille drengs oplevelser i Bronx, New York, i slutningen af $30^{\prime}$ rne. Her lister lidt efter lidt den større historic sig ind $\mathrm{i}$ drengens bevidsthed, både familiens historie og samfundets. Gradvist erkender han forældrenes disharmoniske ægteskab. Begge forældre er børn af indvandrede russiske jøder, men hvor faderens familic repræsenterer en atcistisk, socialistisk tradition, så er moderens skønt kunstncrisk merc småborgerlig og ortodoks. Den halvt senile mormor, som bor hos Edgars familie, står med sine pludsclige aggressionsanfald mod omverdenen for den tunge arv fra progromernes Rusland.

Samfundets historie kommer f.eks. ind i drengens liv gennem radioen, hvor faderen harmfuldt lytter til Hitlers taler og gennem synet af luftskibet Hindenburg, udsendt i propagandaøjemed af Hitler-Tyskland, og Edgar arver hans jødiske antifascistiske bevidsthed. Romanen kulminerer med to smukke skildringer af drengens oplevelsc af verdensudstillingen i New York. Her møder han antydningsvis sexualiteten og billeder af samfundets fremtid. Laseren ved at mange af udstillingens teknologiske visioner allerede er realiseret i nutidens USA, men også at verdenskrigens rædsler er på vej. Meget logisk er Doctorow med sin nye bog Billy Bathgate (1989), som er blevet lovprist af den amerikanske kritik, vendt tilbage til den store historic og de amerikanske myter.

Cynthia Ozick er langsomt i USA og f.eks. også i Sverige ved at få et forljent ry som en spændende kvindelig jødisk forfatter. Hun adskiller sig både starkt fra den mere traditionelle amerikanske kvindelitteratur og fra den mandlige jødiske, fordi Ozick er vokset op i og selv forankret $i$ en religiøs jødisk tankegang. Holocaust og staten Israel spiller en fundamental rolle $\mathrm{i}$ hendes verden, samtidig med at både jødisk mystik og europæisk modernisme, som ofte var skrevet af jøder (f.eks. Kafka og Bruno Schulz), har påvirket hende. Hun definerer det jødiske som det etiske i modsatning til den græskc/hedenske naturdyrkelse. Ofte har hun kredset om det dæmomiske i det æstetiske, jvf. jødernes forbud mod at danne sig billeder af Gud.

På dansk har vi endnu kun fåct den lille roman Kannibal-galaksen (1983, da. 1987) om en jøde, Joseph Brill, der vokser op i Paris som et barn af to kulturer, den ortodokse jødiske og den franske æstetiske, som han drages imod. Inspireret af sine oplevelser og sin læsning under krigen drager han til USA, hvor han bliver leder af en skole, som han vil drive på baggrund af en vision om en syntese af joxdisk og fransk kultur. 
Forsøget mislykkes, og Brill ender som en amcrikansk middclmådighed, fordi han svigter sine rødder.

Efter sigende vil Gyldendal udgive et udvalg af hendes noveller; mens man fortsat overvejer udgivelsen af hendes seneste og bedste roman The Messiah of Stockholm (1987) om den svenske litteraturkritiker Lars Andemening, som forældreløs opbygger en illusion om at være søn af den polsk-jødiske forfatter Bruno Schulz, der blev dræbt af nazisterne under 2. verdenskrig, og hvis manuskript til romanen Messias aldrig er blevet fundet.

Endelig bør i denne jødiske sammenhæng nævnes Arthur Millcrs imponerende erindringsværk Tidens knumning (1987, da. 1988), som ikke blot giver et fint diskret portræt af forfatterens anden hustru, Marilyn Monroe, og af Millers dramatiske forfatterskab, men særlig er et uvurderligt kildeskrift til forståclse af USA's politiske og kulturelle udvikling fra 1939'rnes venstrefløjsmarxisme blandt de intellektuelle over 1950 'crnes McCarthyistiske hekscjagt til 1970'ernes og 1980'ernes postmoderne tvivl om meningen i historien. Erindringerne bære præg af forfattcrens fremragende analytiske cuner og politiske og filosofiske ubestikkelighed.

\section{De sorte}

For et par årtier siden var begrebet »negro» en neutral deskriptiv term. I dag regnes det for nedsattende og racistisk, næesten på linie med »nigger «, og er normalt erstattet af begreber som sort eller afroamerikansk. Bag de terminologiske forskydninger ligger en kulturel og litterær udvikling.

Den sorte litteraturs udvikling er selvsagt kort i USA, men har været intens og praget af nogle bratte politisk betingede skift. I 1920'rne havde man den sorte blucs-inspirerede lyrik »Harlem-renæssancen« med bl.a. Langston Hughes og i 30 'rne f.eks. den i dag genopdagede kvindelige forfatter Zora Neale Hurston. Det store både kunstneriske og folkelige gennembrud fik den sorte litteratur først med Richard Wrights roman $S \phi n$ af de sorte (1940, da. 1942), som på godt og ondt afspejlede volden i de sortes liv, både den der rettes mod dem og den de reagerer med, og forfatterens engagement $\mathrm{i}$ det amerikanske kommunistparti og den dermed forbundne socialrealistiske æestetik.

Efterkrigstidens afpolitiscring og modernistiske/eksistentialistiske strømninger er åbenbare i Ralph Ellisons roman Usynlig mand (1952, da. 
1969), mens James Baldwins romaner og essays både foregreb og afspejlede 60'ernes borgerrettighedsbevacgelser og Luther Kings ikke volds-filosofi på den ene side og modkulturens »make love not war «på den anden. De mere militante holdninger i sentressernes bevægelser som »black power «, de sorte muslimer og det sorte panter-parti, var ikke positive over for fiktionsskrivning, men fandt udtryk i selvbiografier (Malcolm X og Angela Davis) og essays (Eldridge Cleaver).

Alex Haleys roman- og TV-succes Rødder (1976, da. 1977), markerer et tidstypisk vendepunkt bort fra det politisk militante nutidsengagement til en beskæftigelse med den sorte amerikaners afrikanske rødder og kultur. Det er interessen for den afroamerikanske kulturs rødder og aktuelle ytringsformer, som lever så vitalt videre $\mathrm{i}$ den sorte amerikanske kvindelitteratur, at netop den måske i dag repræsenterer den største fornyelse af amerikansk litteratur. Alice Walker og Toni Morrison er de mest fremtradende af en hel gruppe, hvor vi via oversættelser desuden kender Nthzake Shange og Gloria Naylor.

Alice Walkers Farven lilla (1982, da, 1984) blev - også før Spielbergs tamme filmatisering - en international bestseller, sandsynligvis fordi det var let at forholde sig til Walkers historie om, hvordan den sociale undertrykkelse opløser den sorte karnefamilie, og hvordan den sorte kvinde bliver syndebuk for den sorte mands frustrationer. Hvad der virker befriende er den næsten paradoksale optimisme og den religiøst inspirerede livsglæde, som præger bogen, og selv om dens mandeskildringer og dens »lesbiske løsning « har provokeret sorte mandlige intellektuelle $\mathrm{i}$ USA, så virker de rimelige og ikke-propagandistiske.

I sin roman fra 1976 Meridian (1985) giver Walker et billede fra borgerrettighedsbevagelserne i 60'erne og distancerer sig fra de sorte mænds latente voldsbegejstring og macho-chauvisme. I sin nyeste bog The Temple of my Familiar (1989), uddyber Walker de afrikanske forbindelseslinier der lå i historien i Farven lilla om hovedpersonens søster, som rejser som missionær til Afrika, til en filosofisk tankebygning, hvor den afrikanske fortid og det kvindelige ses som basis for en utopi vendt mod en hvid maskulin nutidscivilisation.

Den største af de sorte kvindeforfattere er efter min mening Toni Morrison. Tre af hendes bøger er kommet på dansk. Sula (1973, da. 1985), Salamons sang (1977, da. 1978) og Elskede (1987, da. 1988). Hvad der kendetegner hendes fiktionsunivers er, at de hvide som undertrykkere kun spiller en meget perifer rolle, og at hendes sorte personer er skildret med vitalitet og med en tolerance, samtidig med at hun netop ikke glorificerer dem. Morrison anskuer de sorte i deres historiske situation 
hvor de både er barcre af en traumatisk fortid (slaveriet), som kaster lange skygger, og en fjernere arv fra den afrikanske fortid, der lever videre i de sortes livsglæde, sammenhold og specielle »syngende « form for kristendom. At der $\mathrm{i}$ hendes bøger er en speciel variation af mmagisk realisme « ser jeg ikke blot som en litterær indflydelse fra latinamcrikansk litteratur, men også som et udtryk for magiske elementer i den sorte kultur, som Morrison i Salomons sang tydeligt paralleliserer med indiansk kultur, samtidig med at de har rødder i den afrikanske.

Elskede står for mig som 80 ’ernes vigtigste amerikanske roman, en kunstnerisk helt original beskrivelse af slavcrict og de traumer, det påførte de sorte efter borgerkrigens afslutning. Beskrivelsen af slaveriet er afdampet, fordi hovedpersoncrne ikke var slaver $i$ »the deep South «, men i det nordligere Kentucky. Deres første ejer var en kristen humanist, der behandlede dem forholdsvis humant, og selv den senere ejer, skolelæreren, en kristen fanatiker, som opfatter de sorte som dyr, kunne objektivt set have været værre.

Netop på denne baggrund fremstår slaveriets umenneskelighed klart. Hvad der bliver tydeligt er, hvordan de opløsningstendenser, som moderne sociologer har kunnet se i den sorte kxernefamilie, har sin forklaring i slaverict, hvor familiemcdlemmer blev spredt for alle vinde, så snart det var i slavecjerens $\emptyset$ konomiske interesse. Dertil kom de talrige sexuelle overgreb fra de hvide mænd på de sortc kvinder.

At der ikkc kom helstøbte moralske mennesker ud af en sådan behandling viser Morrison med et Richard Wright-agtigt mod, idet hun lader hovedpersonen Sethe myrde sin cne datter og forsøge at myrde de andre børn, fordi hun frygter, at hun og børnene skal føres tilbage til slaveriet. Det er dette myrdede barn »Elskede«, der vender tilbage til huset i Ohio først som spøgelse og siden materialiserer sig som ca. 20årig kvinde. Fra at vare kærlighedssøgende ung kvinde forvandler hun sig til en vampyr, der suger livet ud af den skyldplagede mor og ødelægger hendes nyetablerede forhold til en gammel ven fra slavetiden. De sorte naboer, inspireret af mindet om Sethes mor, der var en stærk religiøs kvinde, driver den onde ånd ud og muliggør et normalt liv for Sethe, hvor også den sorte mand har en plads.

Morrisons specielle form for sort magisk realisme udspringer af en vilje til at legmeliggøre historiske og psykiske fanomener. Hvad vi ville kalde traumer, skyld og anger materialiseres her forst i form af et spøgelse, der kan salte huset $\mathrm{i}$ rystelse og siden $\mathrm{i}$ en »levende « romanperson. Den langsomme cirklende måde at fortælle historien på, hvor barncmordet først røbes ret sent i historicn, afspejler Scthes manglende 
evne til at se sin handling $\mathbf{i} \not$ jnene. Bogen som helhed derimod fortæller at først ved at vedkende sig sin historic og de sår, den har efterladt, bliver de sorte frie.

\section{Kvinderne}

Jeg hører til dem, der mencr, at begrebet kvindelitteratur efterhånden er ved at miste sin mening, fordi det er for reduktionistisk i forhold til den mangfoldighed af litterære skrivemåder og temaer, der tages op af kvindelige forfattere, og fordi det tilslører forskellen i sociale og kulturelle erfaringer hos kvindernc. Når det $\mathrm{i}$ en amerikansk sammenhæng alligevel giver mening at bruge begrebet på tværs af f.eks. etnisk tilhørsforhold, så cr det fordi amerikansk litteratur i de to sidste årtier har værct præget af en feministisk bølge, som cr blevet båret af en udvidclse af det læsende kvindelige, overvejende middelklassepublikum. Da denne udvikling har varet generel vestlig, har denne litteratur varet yderst velegnet til eksport, og det er i høj grad den moderne amerikanske litteratur, vi kender i Danmark gennem paperback-udgaver og bogklubbøger. Jeg har en fornemmelse af at den amerikanske kvindelitteratur egentlig har haft større betydning i Danmark end i USA, hvor det seriøst lasende kvindelige publikum er relativt mindre.

Den feministiske bølge forbinder vi med navnc som Lisa Alther, Marilyn French, Gail Godwin og Marge Piercy. Deres romaner er brede psykologiske skildringer af væsentlige feministiske tcmaer som mor/datter-forhold, erotiske problemer (både hetero- og homoseksuellc), og konflikten arbejde vs. kærlighed. Samtidig gives deres romaner et aktuelt samtids-billede af USA med 60'ernes og de tidlige 70'er-års alternative bevægelser. Marge Piercy skildrer således i Vida (1979, da. 1982) venstrefløjens situation $\mathrm{i}$ disse år. Gail Godwin og Lisa Alther tematiserer deres baggrund $\mathrm{i}$ det politiske mere tilbagestående Sydstatsmiljø, for Althers vedkommende med stor humor. Erica Jong bliver bestsellerforfatter med speciale i blød selvforelsket porno undertiden i historisk regi. Fanny (1981) var en morsom pastiche på det 17. årh.'s engelske roman à la Ficlding, hendes seneste Serenissima (1987, da. 1988) med Shakespeare som pornoaktør i renæssancens Venedig er et ulideligt genopkog.

Mens disse i Danmark meget populære kvindeforfattere i høj grad afspejler en moderne hvid kvindelig middelklasses erfaringer, så reprasenterer Tillie Olsen en aldre mere proletarisk tradition. Hun blev med rette 
berømt for én novelle - Giv mig en gåde fra samlingen af samme navn (1961, da. 1980) - hvor hun giver en af de mest intense, bitre og ømme skildringer af et gammelt ægtepar, jeg kender. Hendes roman Yonnondi (1974, da. 1983) blev allerede påbegyndt i og reflekterer 30'rnes kriseramte USA.

Baltimore-forfatteren Anne Tyler har et mere varmt og tolerant blik for det »stærke køns « svagheder, f.eks. i den filmatiserede succes-roman Turist ved et tilfoelde (1985, da. 1986). Den unge Jayne Anne Philips er en fremragende novelle-forfatter. I Sorte billetter (1979, da. 1982) og Overhalingsbanen (1987, da. 1988) blander hun en rxkke hverdagsrcalistiske beskrivelser af generationskonflikter med stærke lyrisk skrevne portrætter af amerikanske »outlaws «: forbrydere, narkomaner og ludere. Hendes ambitiøse roman Maskindrømme (1984, da. 1984) giver et lidt for farveløst billede af det tavse Amerika fra 1950'erne til nedturen med Vietnamkrigen.

Allerede i begyndelsen af 1980 'erne begyndte man at tale om den i Danmark ukendte forfatter Joyce Carol Oates som mulig litterær nobelpriskandidat. Til trods for at gætterierne aldrig er blevet til virkelighed, satte de sandsynligvis gang i oversæltelsen af hendes værker. Foreløbig har vi fået 5 romaner, 1 novellesamling og en bog om boksning, men dette er kun et lille udvalg af hedes enorme produktion. ${ }^{4}$

Hendes interesse for den cllers så maskuline boksesport er symptomatisk for et forfatterskab, som i høj grad kredser om magt og vold, både den ydre og den indre psykiske. Oates har et eminent, men også et meget koldt blik, for magtspillet mellem mennesker og volden i samfundet og den amerikanske familie. Hvis det er rigtigt, som den danske dagbladskritik hævder, at romanen Marya (1986, da. 1987) i høj grad er selvbiografisk, så har vi her en forfatter og en universitetsintellektuel, som vokser op ludfattig og uden forældrestøtte, men som via sit $\mathrm{k} \emptyset \mathrm{n}$ og $\sin$ intelligens manipulerer sig op i et mandsdomineret intellektuelt universiıctssystem. De fø̆lelsesmæssige omkomstninger bliver kulden i de personlige relationer og den forbandede evne til altid at se egoismen og magıønskct som de fundamentale menneskelige drivkræfter.

Oates' tematik disponerer hende for at fortsatte den gotiske tradition i amcrikansk litteratur (fra Poe og Hawthorne og Faulkner), og af Faulkner har hun også lært den subtile brug af upålidelige fortællere. Fra sin opadstigning i universitetsverdenen (hun er også universitetsprofessor) har hun givetvis sit skarpe satiriske blik. 


\section{USA set fra neden}

USA's forskellige etniske grupper har alle deres kvindelige forfattere. Jøden Cynthia Ozick og de sorte kvindeforfattere er blevet omtalt. Kineserne har Maxine Hong Kingston (Kvindekrigeren 1976, da. 1982) og Amy Tan. Den indianske kultur er primært mundtlig og mystisk og har derfor ikke produceret så megen skriftlig litteratur. Det er måske karakteristisk, at den ofte skrives af halvblodsindianere med et ben i to lejre. N. Scott Momaday, (mandling) forfatter til Huset bygget af daggry (1968, da. 1987) er halvblods, og det samme gxlder Louise Erdrich.

Hvor det gælder for jøderne og asiaterne, at de relativt nemt har kunnet tilpasse sig det økonomsick system i USA, så minder indianernes sociale situation om de sortes. Enten har indianerne forsøgt at overleve i reservaterne, eller også er de søgt ind til storbyerne, hvor de har haft svart ved at overleve i asfaltjunglen.

Louise Erdrich giver i sin romantrilogi Elskovsmidler (1984, da. 1985), Himmelfugt (1986, da. 1988) og den uoversatte Tracks (1988) et billede af Chippewa-indianerne i North Dakota og deres hvide naboer over et langt historisk stræk. Hun har et skarpt blik for indianernes forfærdelige sociale situation, selvødelæggelsen ved mødet med de hvide, samtidig med at hun fastholder de indianske myters skønhed og værdigheden i deres indianske kultur. Ligesom Toni Morrison finder hun en magisk realisme i den amerikanske virkelighed.

Generelt har den amerikanske litteratur efter 2. verdenskrig været praget af på den ene side en stigende intellektualisering og akademisering af »finlitteraturen « og på den aden sidde en vakst i kulturindustrien. Hvor den sidstnæunte tendens $\mathrm{i}$ høj grad hanger sammen med massemediernes udvikling, så skyldes den førstnævnte bl.a. det generelt højere uddannelsesnievau efter krigen og forfatternes integration i universitetsverdenen gennem undervisningsstillinger, USA's variant af »offentlig « litteraturstøtte. Dertil kom at den kritiske realistiske romantradition, som dominerede amcrikansk littcratur fra århundredets begyndelse til slutningen af 30'rne, fra Upton Sinclair og Theodore Dreiser til Dos Passos og John Steinbeck, brød sammen under indtryk af Stalin-processerne, Hitler/Stalin-pagten og den stigende amerikanske velstand under og efter krigen, og afløstes af en moderat modernistisk litteratur, inspireret fra Europa.

Men som den sorte litteratur, og som en Louise Erdrich, en Tillic Olsen og en Jayne Anne Philips viser, så skrives der stadig litteratur i USA, som beskaftiger sig med de undertryktes erfaringer og oplevelser, selv om denne litteraturs formsprog nappe kan kaldes socialrealistisk. En 
af de mandlige forfattere, som i sin lyrik og først og fremmest i sine noveller har givet det tavse USA stemme, er den fornyligt afdøde Raymond Carver. Det USA, han beskriver, er det vestlige, Oregons og Californiens små gudsforladte flækker, og hans personer kommer fra arbejder- eller den lavere middelklasse. De er ikke så meget fattige i $\emptyset$ konomisk forstand som i eksistentiel. De er svage og uden selvtillid, og deres privatliv er som regel ved at bryde sammen.

Carvers noveller er som regel ultrakorte og starter midt i konfliktsituationen der uden et overflødigt ord føres til et sammenbrud. Med et begreb fra billedkunsten er Carver blevet kaldt »minimalist «. Med et minimum af ord er han $i$ stand til at skitsere en konflikt og antyde komplekse følelser. Inspirationen fra Hemmingways »isbjerg-teknik « er tydelig, men Carvers uartikulerede jeg-svage personer er i høj grad moderne. På dansk er der kommet et fremragende udvalg af hans noveller i samlingen Hvad vi taler om, når vi taler om karlighed i 1985.

Garrison Keillor er en af USA's populæreste radio-entertainere. I sit radioshow Prairie Home Companion skabte han en række monologer om Lake Wobegon, en lille fiktiv flække ude på landet i Midtvesten (Minnesota). Senere omarbejdede han den til bogform, og i Danmark har vi fået dem i 1987: Lake Wobegon og i 1989: Farvel til Lake Wobegon.

Med stor varme og med en pragtfuld understated humor fortæller Keillor om det stille liv og de små glæder og sorger ude på landet blandt nogle mennesker, der ofte har skandinaviske rødder og har videreført en puritansk protestantisk tradition.

William Kennedy slog igennem i USA med sin Albany-triologi: Gangsteren Legs (1975, da. 1988), Billy Phelans Greatest Game (1978, uoversat) og Jernut (1983, da. 1985). Albany er staten New Yorks hovedstad, og den var ligesom byen New York politisk domineret af de irske indvandrere, som satte sig på det demokratiske partiapparat ca. $1860 \mathrm{og}$ dominerede det til langt op i 30'rne. Med sin historiske romantrilogi skriver Kennedy de irske indvandreres mytologi, ligesom Faulkner skrev Sydstaternes. Gangsteren Legs er en gangster i forbudstidens USA, en autentisk irsk variant af Al Capone-skikkelsen, og bogen om ham er en mytc om gangster-skikkclsens storhed og fald, tydelig påvirket af Scott Fitzgeralds Den store Gatsby. Billy Phelan's Greatest Game focuserer i høj grad på det irske magtapparat $\mathrm{i}$ byen, mens den bedste og på grund af filmatiserringen mest kendte roman i trilogien, Jernurt (Ironweed), fortæller en historie om sociale tabere i 30 'rnes krise-USA. Kennedy forholder sig varmt og solidarisk til sine bumsers udviklingshistoric og indlejrer den i noget man - lidt inflatorisk - kunne kalde irsk magisk 
realisme, hvor fortidens traumatiske hændelser og døde personer står op af graven og materialiserer sig i drankercns alkoholiske bevidsthed.

En særlig variant af denne »verden set fra neden«-litteratur finder vi i Bohème-traditionen, der har sine specielle rødder i amerikansk littcratur helt tilbage i Walt Whitmans lyriker-image, men som specielt dyrkedes $\mathrm{i}$ 20'rne og 30'rnes kunstnerkolonier i Paris. Henry Miller var dens mest typiske reprasentant. Bohèmens dyrkelse af erotik, alkohol (eller stoffer), musik og det fric kunstnerliv fortsættes for fuld udblæsning af »the beat generation $\ll$ i 50'erne (Burroughs, Kerouac og Ginsberg) og i hippiekulturen.

Charles Bukowski, »the dirty old man«, er en moderne repræsentant for denne tradition. Hans bøger er med rette blevet beskrevet som Henry Miller minus dennes filosofi. Hans bøger cr ikke stor litteratur, men de har en dejlig rå usentimental antiautoritar tone $\mathrm{i}$ den starkt selvbiografiske skildring af forfatterbumsens drukture, scxuelle oplevelser og hans kamp mod burcaukratiske autoriteter. ${ }^{5}$ Den kultisk dyrkelse af forfatteren blev øget med Mickcy Rourkes portrat af forfatteren i filmen Barfly.

\section{Reagans børnebørn og storbyen New York}

Der er i 1980'ernes USA trådt en rakke helt unge forfattere frem, som gradvis har fået tildelt de ikke helt smigrende etiketter »Reagans børnebørn« eller yuppie-generationen. Begge hentyder dels til publiceringstidspnktet, dels til manglen på politisk interesse og cngagement og en vis selvcentreret kølig narcissisme. De mest fremtrædende blandt denne nye generation er Jay McInerney, Brett Easton Ellis, David Leavitt og Tamia Janowitz.

Denne generations største bestseller har varet McInerneys roman med den smukke amerikanske titel Bright Lights, Big City (1984, da. Af banen 1986) om en ung journalist og forfatteraspirant, der lever et kokainsniffende liv sammen med New Yorks unge jet-set. Han gennemskuer tomheden i det, men driver viljeløst med, langes efter en totalt vardiløs kone, der har forladt ham og savner sin afdøde mor. Det er en tidstypisk senpubertetsroman, en ny Forbandet Ungdom i et nihilistisk storby-miljø. Det forsonende ved den er den humoristiske talesprogsstil, hvormed McInerney spidder miljøet.

Det er svart at vide, hvad man skal kalde denne generation. Bcgreberne fortabt og forbandet, er allerede brugt op, og rigtige yuppiere er 
forfatterne selvfølgclig ikkc. Så ville de ikke skrive fiktion, og så ville de ikkc have en ironisk distance til miljøet. I Brett Easton Ellis' Under nul (1985, da. 1986) gives et frysende portrat, ganske vist i Los Angeles, af en ungdomsorganisation der er ved at gå under i stoffer og almindelig følclscsløshed. Davis Leavitt er bøsse, og det præger både hans novellesamling Familien danser (1984, da. 1986) og hans uoversatte romaner. Leavitt er cn frcmragende psykolog, men også cn megct kølig forfatter. I hans univers er man langt fra 70'ernes tro på det pragtfulde i den alternative kærlighed, hans personer cr ensomme, bange og uengagerede i politik.

Kathy Acker er en lidt special forfattertype, en blanding af punker med et råt kropsligt sexuclt image og en finlitterar postmodernist, som bruger aldre litteratur i pastiche-form og med en Burroughsk cut up-teknik. I den ret ulaselige Don quixote der var en drøm (1986, da. 1986) moderniscrer og sexualiscrer hun Cervantes' »bedrøvelige « ridder.

En noget merc spændende og ganske anderledes ung storbyforfatter er Paul Auster, som fik sit gennembrud med New York-trilogien: By af glas (1985, da. 1987), Genfard (1986, da. 1988) og The Locked Room (1988, da. 1989). De tre bøger, som hører tæt sammen og er udgivet som en bog i Amerikansk paperback, kan bedst beskrives som en blanding af kriminalroman-pastiche og Franz Kafka. Selv om de tydeligt mimer private eyc-genren (à la Chandler og Hammett), og derved placerer sig i en intellcktuel postmoderne tradition, så er de i deres befriende korthed enormt suggestive. Kafka-indflydelsen er åbenbar i bøgernes falles »tomme transcendens «, hvor de søgende, detektiverne, involveres i sager de ikke kan overskue, og ender som anklagede for en forbrydelse eller offer for en likvidering, de ikke kan genneskue. Intertekstualiteten er diskret, men alligevel markant. Forfatteren Paul Auster optræeder som romanperson i By af glas, der diskuteres litteratur i bøgerne, »detektiven« i The Locked Room cr også en slags litteraturforsker, og bøgerne i trilogien refererer til hinanden $i$ et subtilt spil. Paul Auster er en slags lakonisk Umberto Eco eller en Borges, der ved, at et romanreferat kan virke mere spandende end en udpenslet roman.

Afslutningsvis i denne New York-sammenhæng vil jeg nævnc Tom Wolfe's bestseller-roman The Bonfire of the Vanities (1988, da. 1989).

Tom Wolfe har hidtil været kendt som en al hovedmændene i The New Joumalism, en journalistisk inspireret blandingsform af facts og fiktion, hvor han bl.a. analyscrede hippiekulturen, astronauternes liv og moderne amcrikansk arkitcktur. The Bonfire of the Vanities er en forrygende romandebut med byen New York som hovedperson, men den 
bygger på Wolfe's karakteristiske journalistiske og sociologiske approach.

Romanens umiddelbare svaghed er dens personkarakteristik, men netop heri er der måskc også en pointe. Personerne i den har ingen dybde, ingen »sjæl $\left.\right|_{\alpha}$, de er sociale karaktermasker, der determineres af deres sociale, geografiske og etniske tilhørsforhold. Wolfes satire spidder både high society på Park Avenue, de småborgerlige karrieredrømmere i retsmaskineriet, mediefolkene, og den sorte revolutionære præst. Der er ingen idealister i Wolfe's kyniske New York-billede, det skulle da lige være den jødiske dommer, der selvfølgelig ikke genvælges, da han nægter at spille spillet.

Bogen er en spandingsroman om en succesrig obligationsspekulant, der en dag henter sin elskerinde i lufthavnen. På vejen tilbage til Manhattan kører de galt og ender i Bronx, hvor de i skræk for to unge sorte, kommer til at køre den ene ned, så han senere dør. Situationen er tvetydig og skyldsspørgsmålet uklart. Ville de sorte hjælpe eller var de forbrydere? Er obligationsspekulanten skyldig, når det var hans elskerinde, der havde overtaget rattet?

Pointen i det efterfølgende forløb, som fører til retssag, først frifindelse og dernæst dom og hovedpersonens totale sociale deroute, er at systemet kræver hans fald. De sorte kan bruge ham i deres politiske kampagne, og den jødiske borgmester og den jødiske statsadvokat må ofre ham for at bevare et ikke-racistisk image $\mathrm{i}$ valgkampen. ${ }^{6}$ Systemet kan sagtens overleve ofringen af et individ, magthavere og oppositionen har fælles interesse.

\section{Amerikansk litteratur set udefra. En epilog.}

Det er et faktum, at den globale kultur efter 2, verdenskrig er blevet mere og mere amerikaniscret, og det afspejler sig bl.a. i vores fiktionsforbrug af film, TV-serier og litteratur. Vores oversattelseslittcratur er helt overvejende angelsaksisk dominerct. Dertil kommer, at USA er et kæmpekontinent, og derfor må der selvfølgelig i en sådan oversigtsartikel være store huller. Jeg kan selv pege på forfattere som John Updike, Kurt Vonncgut og John Irving.

Et ganske andet spørgsmål cr: hvor god, original og fornyende er den amerikanske litteratur i dag? Svaret er ikke ganske enkelt. Mange amerikanske litteraturhistorikere ser den amerikanske litteraturs udvikling i dette århundrede som en forfaldshistorie. Det absolutte højdepunkt var 20 'rnes romanforfattere Faulkner, Hemmingway, Fitzgerald og Dos Passos 
(her gik påvirkningen for en gangs skyld fra USA til Europa). Et andet og mindre højdepunkt var den eksistentielle, moderat modernistiske jødiske efterkrigstidslitteratur. Efter den er den åndelige energi sluppet op, og litteraturen er blever delt op i to kredsløb, et stadig smallere akademisk, hvor den postmoderne opfattelse af at de store fortællingers tid er forbi har ført til en række »smalle fortællinger«, der i dekonstruktiv ånd primært ser sit formål i at reflektere over sig selv som fiktion, og så et stadigt ekspanderende kulturindustrielt kredsl $\varnothing \mathrm{b}^{7}$

Et sådant signalement er ikke uden en vis sandhed og hæenger sammen med nogle kulturelle skred $\mathrm{i}$ hele den vestlige verden. Man kan, når man sammenligner den amerikanske (og den vesteuropæiske) litteratur med tredje verdens forfatter som f.eks. Garcia Marquez og Rushdie, godt fornemme, at den vestlige verdens forfattere mangler en sag at kampe for, et menneske at tro på og en levende fortælletradition at trække på.

Når sandheden i signalementet alligevel er begrænset skyldes det flere faktorer. For det første kan den postmoderne fiktion godt skrives med så stor vitalitet, som det f.eks. sker hos Philip Roth og Paul Auster, at den udsiger noget vasentligt om relativismen $\mathrm{i}$ den postmoderne verden. Kulturindustriens ckspansion fører undertiden til en kvalitetsforbedring som hos f.eks. Stephen King, der ophæver skellet mellem fin og populærlitteratur. Tom Wolfe's Bonfire of the Vanities giver på godt og ondt et fremragende billede af storbyjunglen i spændingsromanens form.

Og endelig - og det cr måske de væsentlige - den amerikanske kultur er så fuld af modsætninger og brudflader, at stadig nye stemmer kommer til. Alice Walkers, Toni Morrisons og Louise Erdrichs romaner har nye kulturers vitalitet, samtidig med at de trækker på hidtil usynlige traditioner, og en Joyce Carol Oates beskriver med satanisk veloplagthed volden og magtstrabet i WASP-kulturen. ${ }^{8}$ De amerikanske bestseller-lister viser stor kulturindustriel dominans, men samtidig at disse mere eksperimenterende forfatter faktisk har et stort lydhørt publikum.

\section{Noter}

1. For en mere grundig behandling af nyere jødisk-amerikanske litterater, se min artikel : Den jødiske erobring af amerikansk litteratur. Kritik 88. 1989.

2. Malcolm Bradbury taler i Columbia Literary Ilistory of the United States (1988) om en eksistentiel eller moralsk realisme.

3. Den egentlige Zuckerman-serie består af: 1. The Ghost Writer (1979, da. Forfatterspire 1981). 2. Zuckeman Unbound (1981, da. Den befriede Zuckeman 1982). 3. The Anatomy Lesson (1983 da. Anatomitimen 1984). 4. The Prague 
Orgy (1985). Roth samlede alle bøgerne i ét bind: Zuckemman bound. $A$ Triology and Epiloge, i 1986.

4. Følgende af Joyce Carol Oates' romaner foreligger på dansk: Mordeme (1975, da. 1981). I de dyre kredse (1968, da. 1982). Solhverv (1985, da. 1986). Marya (1986, da. 1987) og You must remenber this (1988, da. 1988). Desuden novellesamlingen Granser (1976, da. 1983) og Om boksning (1987, da. 1988).

5. På dansk er der kommet 3 bøger af Bukowski: Novelle-samlingen Stiverter, sjoferter, svinagtigheder og hverdagshistorier om almindeligt afsind (1980), og de to romaner: Al magt til ekstrabindene (1981) og Alt forefaldende arbejde (1983).

6. I sin kritik af retssystemest politiske interesser er Wolfe's bog helt på linie med en anden fremragende amerikansk spandingsroman: Scott Turow: Måske uskyldig (1987, da. 1988).

7. Jvf. Charles Newmans kritik af postmodernismen i The Post-modem Aura. The Act of Fiction in an Age of Inflation (1985).

8. WASP $=$ White Anglo Saxon Protestant. 